\title{
Assessment of the Domestic Water Profile of the Region Surrounding Al-Ghadir River, Mount Lebanon
}

\author{
Amale Mcheik*, Aida Ibrik, Rawane Mehdi, Jamil Houhou \\ Environmental Health Research Lab (EHRL), Faculty of Sciences V, Lebanese University, Nabatieh, Lebanon \\ Email address: \\ amale.am@hotmail.com (A. Mcheik), mhareb@hotmail.com (A. Ibrik), rawan_1993@hotmail.com (R. Mehdi), \\ jamil.houhou@hotmail.fr (J. Houhou) \\ *Corresponding author
}

To cite this article:

Amale Mcheik, Aida Ibrik, Rawane Mehdi, Jamil Houhou. Assessment of the Domestic Water Profile of the Region Surrounding Al-Ghadir River, Mount Lebanon. International Journal of Environmental Monitoring and Analysis. Vol. 5, No. 5, 2017, pp. 123-127.

doi: $10.11648 /$ j.ijema.20170505.11

Received: August 16, 2017; Accepted: August 30, 2017; Published: September 22, 2017

\begin{abstract}
The World Health Organization (WHO), in its Guidelines for Drinking Water Quality, defines domestic water as the "water used for all usual domestic purposes including consumption, bathing and food preparation". Today, securing adequate safe drinking water and proper sanitation became a major challenge facing Lebanon. This work is a case study with objectives the assessment of the domestic water profile of the region surrounding Al-Ghadir River at Kfarshima and Al-Sahra. Samples were collected from 3 types of household water sources (Municipality water, Private wells and Water Vended Gallons) and assessed for their physiochemical and bacteriological profile. Results showed deterioration pattern in domestic water quality profile in the three water sources. The measured physiochemical and bacteriological parameters indicates the degree of deterioration of private well sources by the sea and the wastewater infiltration necessitating the enforcement of legislations associated with the use and the management of private wells, municipality water and private vending water.
\end{abstract}

Keywords: Bacteriological Quality, Municipality Water, Well Water, Water Vended Gallons, Physiochemical Characteristics, Al-Ghadir River Region

\section{Introduction}

The World Health Organization (WHO), in its Guidelines for Drinking Water Quality, defines domestic water as the "water used for all usual domestic purposes including consumption, bathing and food preparation" [1].

Lebanon is facing today a deterioration in its water resources specifically its drinking and groundwater resources and this is not only due to climate change and saline intrusions but also due to an increase in water anthropogenic activities and improper integrated management of its water resources. Today, the management of providing safe drinking water and proper sanitation became a major challenge facing this country. The key problems are encountered in providing water to overpopulated cities, such as Beirut and its suburbs [2]. These suburbs are the residence of about 3.8 million citizens, which constitute one third of Lebanon's total population according to the projected figure for the year 2001
[3]. The surface area of Beirut's suburbs is about $28 \mathrm{~km}^{2}$ with a population density of 25,400 [4].

Recent attempts to estimate water demands and availability in Lebanon and Beirut have revealed a significant deficit. Domestic water need in Lebanon is estimated at $850,000 \mathrm{~m}^{3} /$ day, with $450,000 \mathrm{~m}^{3} /$ day available [5]. Beirut alone needs $280,000 \mathrm{~m}^{3} /$ day, where only $180,000 \mathrm{~m}^{3}$ is accessible [6] [7].

Beirut water authorities are the main suppliers of water for the capital and its suburbs. But the scarcity of water in Beirut has led these authorities to apply some drastic measures, such as rationing the water supply to $10 \mathrm{~h}$ every other day [7]. Therefore, it is highly probable that water contamination is also induced throughout the distribution system by the negative pressure and inward suction during cutoff periods [8]. Water rationing as a remedial action, has become a firmly established practice for the past 4 decades. Consumers as such are resorting to using other complementary water sources. These sources are provided by water vendors, the 
industrial sector and by pumping private wells.

Exploitation of ground water through private wells is uncontrolled and is still increasing up to the present time [5]. The excessive exploitation of ground water over the years has led to the infiltration of seawater and the deterioration of the fresh water aquifer [8] [9] [10] [11]. Parallel to the extraction of water from private wells, water shops are mushrooming. The estimated number of these shops is not available due to the complete absence of quality-control monitoring legislations. These practices have exposed the citizens to contaminated water and its resulting health problems [7] [12] [13] such as gastrointestinal diseases which are mainly due to fecal contamination of drinking water resulting from deficiencies in storage tanks and crossconnections of sewer pipes with domestic water [8]. Even though the assessment of the relative disease burden is deficient, still the disease registry of the Public Health Ministry is reporting increasing incident rates of diarrhea, dysentery and typhoid [12] [14] [15] and this is not only from contaminated water, but also from the vegetables irrigated from contaminated wells [16]. In addition to this problem, the rapid increase in urban population challenges the ability of the public sector to comply with water demands [17] [18] [19] and therefore households transfer to a number of other alternatives or complementary water sources that satisfy their need. These sources vary from owning private wells, "water vending and vended water bottles" and bottled water [7] [8] [13] [20] and again this problem has in turn aggravated the health problems. Therefore, the objective of this study is an assessment of the domestic water profile for Al-Ghadir region in the suburbs of Beirut. This assessment is attained through physical, chemical and microbiological analysis of domestic water samples.

\section{Materials and Methods}

\subsection{Sampling}

Domestic water was collected during the dry season from 75 houses from the house tap. The sampling sites (houses) were chosen based on the availability of municipality and/or complementary well water. In addition to the house tap samples, 75 Water Vended Gallons samples from 3 companies were also sampled from the same houses. Samples were taken from Kfarshima and Al-Sahra region near Al-Ghadir River. This region is highly populated with moderate drilling of private wells. This region suffers from a shortage in the municipality water especially during the dry season and therefore it depends on well water. Both municipality and well waters are not used for all domestic purposes, they are used only for cleaning and bathing and water vended bottles were used for consumption and food preparation. Water samples $(300 \mathrm{ml})$ were collected in borosilicate glass bottles for bacteriological analysis. In addition, a 1-1 polyethylene bottle soaked overnight with $10 \% \mathrm{v} / \mathrm{v}$ nitric acid was also used for water sampling collection. The method of sampling and collection are in accordance with Standard Methods for the Examination of Water and Wastewater [21].

During sampling, a survey was also done to know for what purposes each type of water is used.

\subsection{Field Analysis}

Parameters sensitive to environmental changes were measured on site. Temperature, electrical conductivity $\left(\mathrm{EC}_{\mathrm{w}}\right)$, $\mathrm{pH}$, Eh, dissolved oxygen (DO) and total dissolved solids (TDS) were measured using Real time data logger model: YK-2005WA.

\subsection{Laboratory Analysis}

The collected water samples were divided in two bottles. One bottle was acidified with nitric acid to $\mathrm{pH}<2$ and stored at $4^{\circ} \mathrm{C}$ for the analysis of $\mathrm{Na}$ by the flame photometer technique, and Fe by AAS. Working standard solutions were prepared by dilution of stock solutions ( $1 \mathrm{mg}$ metal $/ \mathrm{ml}$ in $2 \%$ $\mathrm{HNO}_{3}$ ) with milliQ water. The other bottle was stored at $4{ }^{\circ} \mathrm{C}$ without the addition of preservatives for the analysis of water major parameters: titration procedure was used for alkalinity (0.02 $\left.\mathrm{N} \mathrm{H}_{2} \mathrm{SO}_{4}\right), \mathrm{Cl}^{-}(0.014 \mathrm{~N}$ mercuric nitrate), $\mathrm{Ca}, \mathrm{Mg}$ and total hardness (0.01M EDTA) and spectrophotometric for $\mathrm{NO}_{3}^{-}$(Cadmium reduction), $\mathrm{SO}_{4}{ }^{2-}$ (turbidimetry) and $\mathrm{PO}_{4}{ }^{3-}$ (Ascorbic acid). The bacteriological quality was determined by membrane filtration technique (Millipore).

\subsection{Statistical Analysis}

The statistical analysis of the physiochemical parameters was performed using the SPSS software.

\section{Results and Discussion}

\subsection{Water Quality Profile of Well Water, Municipality Water and Water Vended Gallons}

The mean values of the various measured physiochemical parameters of Well water are presented in Table 1, Municipality water in Table 2 and Water Vended Gallons in Table 3. Water samples were collected during the dry season from houses in Kfarshima and Al-Sahra regions near AlGhadir River. This sampling was done to assess the water quality profile of this region which showed to be miserable not only from the presence of Al-Ghadir River which is highly polluted but also from the different domestic water types utilized by the people living in the region. This very poor and highly populated region utilize the three water type sources for their domestic activities.

\subsubsection{Well Water}

During the dry season, the recharge of groundwater is nil and this leads to limited dilution of water parameters and water use is at its highest peak. During this season also, the Lebanese Water Authorities augment the deficiency in the supply of the water resources to this region and this explains the reason of the high mineral content present in both well and municipality waters. Beginning with well waters, a very 
high mineral content was observed in these samples. The conductivity, the TDS levels and the concentrations of $\mathrm{Cl}^{-}$, $\mathrm{Na}^{+}, \mathrm{SO}_{4}{ }^{2-}$ and $\mathrm{Fe}^{2+}$ were above the drinking water standards recommended by the USEPA [22]. The mean conductivity value for collected samples is $3,669 \mu \mathrm{S} / \mathrm{cm}$ and is three times higher than the recommended upper limit of $1,250 \mu \mathrm{S} / \mathrm{cm}$. The chloride $\left(\mathrm{Cl}^{-}\right)$concentration of $1622 \mathrm{mg} / \mathrm{l}$ is even six times larger than the USEPA recommended upper level of $250 \mathrm{mg} / \mathrm{l}$. The concentrations of $\mathrm{Ca}(=151 \mathrm{mg} / \mathrm{l})$ and of $\mathrm{Mg}$
$(=89 \mathrm{mg} / \mathrm{l})$ are also higher than the set standards by USEPA. Though WHO [19] does not indicate the health hazards resulting from a considerable excess in ion concentrations, such as $\mathrm{Cl}, \mathrm{Mg}$ and $\mathrm{Ca}$ and there is an absence of existing data relevant to human health effects from high concentrations of these ions, still these ions affect the household infrastructure and impact the corrosion of domestic pipes, the leaching of metals and the water taste [8] [19].

Table 1. Measured physiochemical parameters of well water samples.

\begin{tabular}{|c|c|c|c|c|c|c|c|}
\hline \multirow{2}{*}{ Parameter } & \multicolumn{4}{|c|}{ Well water samples $(N=75)$} & \multicolumn{3}{|c|}{ Drinking water guideline } \\
\hline & Mean & Min & Max & SD & WHO & EEC & USEPA \\
\hline Temperature ${ }^{\circ} \mathrm{C}$ & 23.05 & 15.7 & 30.4 & 5.1 & - & - & 25 \\
\hline $\mathrm{pH}$ & 7.97 & 7.25 & 8.84 & 0.52 & $6.5-8.5$ & $6.5-8.5$ & $6.5-8.5$ \\
\hline Eh (mVolt) & 132 & 53 & 187 & 85 & - & - & - \\
\hline TDS (mg/l) & 2,430 & 875 & 3,985 & 824 & 1,000 & - & 500 \\
\hline Conductivity $(\mu \mathrm{S} / \mathrm{cm})$ & 3,669 & 2,214 & 7,125 & 2,728 & - & $400-1250$ & - \\
\hline DO (mg/l) & 6.01 & 3.56 & 8.45 & 2.30 & - & - & - \\
\hline $\mathrm{Ca}(\mathrm{mg} / \mathrm{l})$ & 151 & 118 & 185 & 18 & - & 100 & 100 \\
\hline $\mathrm{Mg}(\mathrm{mg} / \mathrm{l})$ & 89 & 54 & 124 & 82 & - & 30 & 30 \\
\hline $\mathrm{PO}_{4}(\mathrm{mg} / \mathrm{l})$ & 0.48 & 0.12 & 0.85 & 0.15 & - & 0.4 & - \\
\hline $\mathrm{NO}_{3}(\mathrm{mg} / \mathrm{l})$ & 14.51 & 1.32 & 27.71 & 2.30 & 10 & $5-10$ & 10 \\
\hline $\mathrm{SO}_{4}(\mathrm{mg} / \mathrm{l})$ & 78 & 31 & 123 & 30 & 250 & $25-250$ & 250 \\
\hline $\mathrm{Cl}(\mathrm{mg} / \mathrm{l})$ & 1622 & 548 & 2852 & 647 & 250 & 25 & 250 \\
\hline $\mathrm{Na}(\mathrm{mg} / \mathrm{l})$ & 1550 & 328 & 2780 & 1530 & - & - & - \\
\hline
\end{tabular}

The high reported conductivity, $\mathrm{Mg}^{2+}$ and $\mathrm{Cl}^{-}$ concentrations in well water samples are primarily due to sea water intrusion, high rate of water extraction and can be due to domestic wastewater infiltration but cannot be due to natural water type occurence. This high content of chloride does not imply a health hazard but it affects taste of water [1]. The mean $\mathrm{pH}$ values for well water samples $(\mathrm{pH}=8)$ were typical for water arising from carbonate bedrock [23]. Examining additional parameters, such as $\mathrm{NO}_{3}^{-}$ concentrations, it was determined that its mean value is $14.51 \mathrm{mg} / \mathrm{l}$ with a maximum value of $27.71 \mathrm{mg} / \mathrm{l}$. Both the mean and the maximum concentrations values exceed both the recommended standards of USEPA and WHO $(=10 \mathrm{mg} / \mathrm{l})$. Nitrate concentrations higher than $10 \mathrm{mg} / \mathrm{l}$ are the cause of methemoglobina (blue-baby syndrome) [19]. The presence of $\mathrm{NO}_{3}{ }^{-}$in water reflects an additional water deterioration profile resulting from the improper management of domestic sewage. Although regulations recommend providing septic tanks, these are replaced by cesspools because of the improper enforcement of regulations.

\subsubsection{Municipality Water}

Compared to the well water, a lower mineral content was recorded for the municipality water which showed also to be lower than the recommended values set by both USEPA and WHO. The mean conductivity value $(=1550 \mu \mathrm{S} / \mathrm{cm})$ was lower than that of well water but was still higher than the lower recommended USEPA value level for drinking $(=400$ $\mu \mathrm{S} / \mathrm{cm}$ ). The concentrations of chloride in municipality water showed to be higher than the maximum limit $(=250 \mathrm{mg} / \mathrm{l})$ recommended by the USEPA for drinking. These high $\mathrm{Cl}^{-}$ concentrations in municipality water are most probably the outcome of mixing well water with municipality water during the dry season in houses that use both water sources (Municipality and Well).

Table 2. Measured physiochemical parameters of Municipality water samples.

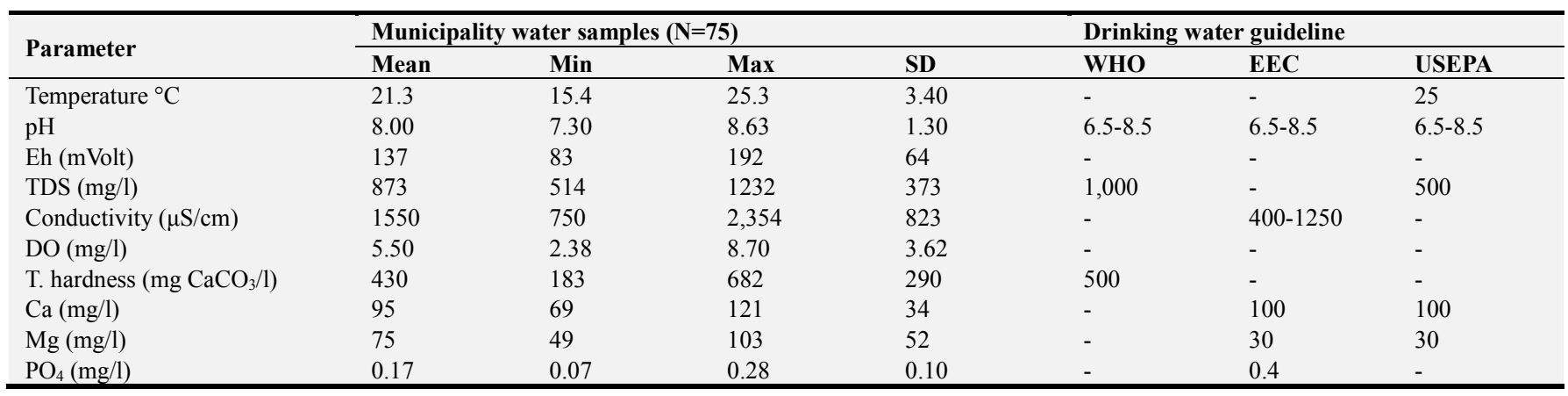




\begin{tabular}{|c|c|c|c|c|c|c|c|}
\hline \multirow{2}{*}{ Parameter } & \multicolumn{4}{|c|}{ Municipality water samples ( $N=75)$} & \multicolumn{3}{|c|}{ Drinking water guideline } \\
\hline & Mean & Min & Max & SD & WHO & EEC & USEPA \\
\hline $\mathrm{NO}_{3}(\mathrm{mg} / \mathrm{l})$ & 3.14 & 1.12 & 5.17 & 2.72 & 10 & $5-10$ & 10 \\
\hline $\mathrm{SO}_{4}(\mathrm{mg} / \mathrm{l})$ & 70 & 32 & 108 & 36 & 250 & $25-250$ & 250 \\
\hline $\mathrm{Cl}(\mathrm{mg} / \mathrm{l})$ & 350 & 138 & 562 & 320 & 250 & 25 & 250 \\
\hline $\mathrm{Na}(\mathrm{mg} / \mathrm{l})$ & 280 & 93 & 483 & 240 & - & - & - \\
\hline $\mathrm{Fe}(\mathrm{mg} / \mathrm{l})$ & 1.3 & 0.13 & 2.63 & 0.78 & 0.3 & $0.05-0.20$ & 0.3 \\
\hline E. coli & $39 \%$ & & & & & & \\
\hline
\end{tabular}

\subsubsection{Water Vended Gallons}

The average concentration of major water indicators in water vended gallons (WVG) was within the acceptable standard levels (Table 3).

\subsection{Bacteriological Water Quality Profile}

According to the WHO guidelines [1], all water intended for drinking must be free from fecal coliform bacteria. While assessing the microbial profile of collected water samples, data revealed that the most contaminated domestic water type source is well water.

Fecal coliform was reported in $62 \%$ of well water samples. The occurrence of this high contamination is due to (a) the infiltration of wastewater into aquifers or wells, resulting from the old deteriorating sewage network in this region, (b) the use of cesspools and (c) the cross-connection between domestic sewer pipes and domestic water pipes. What should be noted is that this water is used also for irrigation of the agricultural lands present in the region and a study was done on the irrigated vegetables showed that these vegetables were contaminated.

Fecal coliforms were reported in $39 \%$ of municipality water. This high contamination level also is due to deficient free residual chlorine to cope with contamination in the distribution network and could also be due to mixing of well water with common house municipality water tanks and /or cross-connection of wastewater pipes with domestic water pipes.

Water Vended Gallons showed the lowest contamination level with fecal coliforms reported in $10 \%$ of samples. This low percentage of contamination of this type of water is considered high especially that the community in this region depends heavily on this water for cooking, drinking and sometimes for washing because they know that both well and municipality waters aren't clean and they experienced several cases of sickness (vomiting and diarrhea) related to consuming both well and/or municipality waters for drinking. The degree of contamination of this water has decreased during the last ten years. This decrease is due to the regulations putted for water shops and companies selling potable water (Decree issued in 1976 and enforced in 1983) and which require a permit from the Ministry of Health and another from the Ministry of Trade, as well as compliance with drinking water standards and minimal labeling requirements [13].

Table 3. Measured physiochemical parameters of Water Vended Gallons samples.

\begin{tabular}{|c|c|c|c|c|c|c|c|}
\hline \multirow[t]{2}{*}{ Parameter } & \multicolumn{4}{|c|}{ Water Vended Gallons samples $(\mathbf{N}=75)$} & \multicolumn{3}{|c|}{ Drinking water guideline } \\
\hline & Mean & Min & Max & SD & WHO & EEC & USEPA \\
\hline Temperature ${ }^{\circ} \mathrm{C}$ & 21 & 19 & 23 & 2.4 & - & - & 25 \\
\hline $\mathrm{pH}$ & 7.65 & 7.5 & 7.8 & 0.21 & $6.5-8.5$ & $6.5-8.5$ & $6.5-8.5$ \\
\hline TDS (mg/l) & 305 & 172 & 439 & 134 & 1,000 & - & 500 \\
\hline DO (mg/l) & 8.51 & 7.73 & 9.3 & 1.73 & - & - & \\
\hline T. hardness $\left(\mathrm{mg} \mathrm{CaCO}_{3} / \mathrm{l}\right)$ & 189 & 122 & 57 & 121 & 500 & - & - \\
\hline $\mathrm{Mg}(\mathrm{mg} / \mathrm{l})$ & 23.8 & 14 & 33.6 & 18 & - & 30 & 30 \\
\hline $\mathrm{PO}_{4}(\mathrm{mg} / \mathrm{l})$ & 0.155 & 0.08 & 0.23 & 0.07 & - & 0.4 & - \\
\hline $\mathrm{NO}_{3}(\mathrm{mg} / \mathrm{l})$ & 5.06 & 1.52 & 8.60 & 2.52 & 10 & $5-10$ & 10 \\
\hline $\mathrm{SO}_{4}(\mathrm{mg} / \mathrm{l})$ & 22.72 & 13.45 & 32 & 9.57 & 250 & $25-250$ & 250 \\
\hline $\mathrm{Cl}(\mathrm{mg} / \mathrm{l})$ & 60.4 & 42.5 & 78.3 & 3.42 & 250 & 25 & 250 \\
\hline $\mathrm{Na}(\mathrm{mg} / \mathrm{l})$ & 14.57 & 9.23 & 19.34 & 1.57 & - & - & - \\
\hline $\mathrm{Fe}(\mathrm{mg} / \mathrm{l})$ & 0.228 & 0.127 & 0.27 & 0.03 & 0.3 & $0.05-0.20$ & 0.3 \\
\hline
\end{tabular}

\section{Conclusion}

This study has assessed domestic water quality of one of the most populated regions in the suburbs of Beirut. Based on the results, it is evident that the situation is deteriorating at a fast pace due to the contamination of domestic well water from seawater and wastewater intrusions. Wastewater intrusions arise from the cross connection of sewer pipes with domestic pipes. These results emphasized the need to: (a) promote awareness among end users of their water quality, (b) protect groundwater aquifer, (c) provide safe adequate water supplies, (d) implement proper management of domestic wastewater for the suburbs of Beirut. Initiating and sustaining these activities will protect and promote public health, reduce disease burden and achieve socioeconomic growth and development. 


\section{References}

[1] WHO (2004). Guidelines for drinking-water quality. Volume 1. Recommendations, 3rd edn. Geneva, Switzerland.

[2] Jurdi, M., Abed Al-Razzzak, M., \& Bassma, S. (2003). The introduction of water resources management in Western Asia region. Water Policy, 5(3), 253-268.

[3] United Nation-UN. (2001). World urbanization prospects. UN Department of Economic and Social Affairs, Population Division.

[4] Ministry of Environment-MEO. (2001). Lebanon State of the Environment Report-Water (Chap. 8).

[5] Korfali, S., \& Jurdi, M. (2009). Provision of safe domestic water for the promotion and protection of public health: a case study of the city of Beirut, Lebanon. Environmental Geochemical Health, 31: 283-295.

[6] Jaber, B. (1997). Water in Lebanon: Problems and solutions. Public lecture given in the Department of Hydrology, Purdue University, Lafayette, IN, April 1997.

[7] El-Fadel, M., Maroun, R., Semerjian, S., \& Harajli, H. (2003). A health-based socio-economic assessment of drinking water quality: The case of Lebanon. Management of Environmental Quality, 14(3), 353-368.

[8] Korfali, S., \& Jurdi, M. (2007). Assessment of domestic water quality: Case study, Beirut, Lebanon. Environmental Monitoring and Assessment, 135, 241-251.

[9] Acra, A., Raffoul, Z., \& Karahogopian, N. (1983). Long-term investigation of sea water infiltration and ground water quality in Greater Beirut. In MESAEP, proceedings: Second international meeting on environmental pollution in the Mediterranean region, Iraklion, Crete, 6-7 September 1983.

[10] Lababidi, H., Shatela, A., \& Acra, F. (1987). The progressive salination of ground water in Beirut, Lebanon. International Journal of Environmental Studies, 30, 203-208.

[11] Acra, A., \& Ayoub, G. M. (2001). Indicators of coastal groundwater quality changes induced by seawater infiltration. International Journal of Environmental Studies, 58, 761-769.
[12] Al-Safir Newspaper. (2002). Official examinations confirm water pollution. Al-Safir Newspaper, 14 February (in Arabic).

[13] Basma, S. (2004). Complementary water sources in a selected urban area in Beirut, Lebanon: Public perceptions, regulations and quality. MS thesis, Department of Environmental Health, Faculty of Health Sciences, American University of Beirut, Lebanon.

[14] United Nations Development Program-UNDP. (1995). Online, available at: www.undp.org.lb/programme/governece/advocacy/hdr97/chp3 1.pdf.

[15] Ministry of Health-MOH. (2000). Compilation of Lebanese epidemiological newsletter. Epi News 1995-2000.

[16] Mcheik, A., \& Ibrik, A (2017). Bacterial contamination of water in the agricultural region near Al-Ghadir River, Mount Lebanon. To be submitted.

[17] Bennet, E. B. (1998). Public-private cooperation in the delivery of urban infrastructures services (water and waste). United Nations, Development Program-Public Private Partnerships (UNDP-PPP), Yale.

[18] United Nation-UN. (2003). Water for people, water for life. UN World Water Development Report (WWDR).

[19] WHO. (2006). Guidelines for drinking-water quality: First addendum to third edition. Volume 1 Recommendations. Geneva, Switzerland.

[20] Kjellen, M. (2000). Complementary water systems in Dar es Salaam, Tanzania: The case of water vending. Water Resource Development, 16, 143-154.

[21] APHA - American Public Health Association (1998). Standard methods for the examination of water and wastewater, 20th edn. Washington DC: American Public Health Association.

[22] United States Environmental Protection Agency-USEPA. (2003). National primary drinking water standards, EPA 816-F03-016. Available at www.epa.gov./safewater.

[23] Stumm, W., \& Morgan, J. J. (1996). Aquatic chemistry, chemical equilibria and rates in natural waters, $3 \mathrm{rd}$ edn., Chap. 10., Trace metals: Cycling, regulation, and biological role. New York: Wiley. 